\title{
A Study of Growth Trends in Contemporary Art in Yenagoa: A Historical Account from 1996-2016
}

\author{
Wenibaraebi Patterson Ugo \\ Department of Fine and Applied Arts, Isaac Jasper Boro College of Education, \\ PMB 74, Sagbama, Bayelsa State, Nigeria \\ Professor Freeborn Odiboh \\ Department of Fine and Applied Arts, University of Benin, PMB 1154, Benin City, Nigeria
}

\begin{abstract}
Most of the present day artists in Yenagoa, whose artworks have enriched the contemporary art scene in Bayelsa State within the past two decades (1996 to 2016), have not gained much recognition as their counterparts elsewhere in Nigeria, such as those in Lagos, Abuja, amongst others. The reason for this setback has been linked to lack of those basic elements or factors that aid the growth of art in the State. This has its crippling effect on art and its practice in Yenagoa. Consequently, this paper seeks to document the gradually developing trends of contemporary art in Yenagoa. It investigates the factors aiding, or militating against the growth of contemporary art in Yenagoa. The study was entirely carried out on the field, and the method of data collection was by personal interviews. Data from secondary sources were used as well. It adopted the art historical method of enquiry in the humanities, and the approach was basically contextual. The study determined that the growth of contemporary art practice in Yenagoa is hindered by certain factors which range from the dearth of art space, and little or no funding for the artist due to low clientele base; and non-sponsorship for the artist by the government. These factors have resulted in lack of regular exhibitions and nonexistence of other programmes which are fundamental to the development of art.
\end{abstract}

Keywords: art criticism, artistic ecology, art space, clientele

DOI: $10.7176 / \mathrm{ADS} / 72-02$

Publication date: April $30^{\text {th }} 2019$

\section{Introduction}

Just about the time traditional art of Africa was in a state of being stereotypical in the eyes of the West in the early $20^{\text {th }}$ Century, the evolvement of Western modern art changed the trend. The new fame that came to African art leveraged on the emergence of Western modern art in the turn of the early 1900s, when "Henri Matisse, Pablo Picasso, and their school of Paris friends blended the highly stylized treatment of the human figure in African sculptures with painting styles derived from the post-Impressionist works of Cezanne and Gauguin" (Murrel, 2008). Not long, political and socio-economic involvement in the colonial world by the West brought in strong Western influence into those lands. In Africa, the new experience with colonialism, new money economy, Western type of education, and a modern way of life also resulted in a new type of art -the modern art. African modern art has since ceded from the nomenclature of modern art to 'Contemporary African Art'.

There are documented information about the art of Africa from the pre-colonial (traditional), through the colonial period, to the contemporary. The influence of Nigerian art in the art tradition from Africa is large. It has placed the country among renown art centers in the world. While the contemporary art, which used to be called modern African art in the years between independence permeate until the 1980s has developed tremendously, African artists have continued to play key role in the turn of artistic events in the world. Artists from Nigeria like Bruce Onobrakpeya, Sokari Douglas Camp, Yinka Shonibare, Ghanaian born-Nigerian artist El Anatsui, have continued to illuminate the world's consciousness on the artistic productivity and current flowing in Nigeria. Certainly, Nigeria has proved to be a leading art concern in Africa, and artworks of Nigerian artists are in some of the most significant galleries around the world. Their works have also featured in Biennials such as the Documents, and other exhibitions. It is also very pertinent that the Nigerian Okwui Enwenzor, poet, art critic, art historian and curator became the first African director of the Venice Biennale in 2015 (McKean, 2015).

Contemporary art in Nigeria has developed with new features that were not known in Nigerian art scene before now. Among these, is the increasing number of art galleries, art departments of the academia, and the rising patronage of the arts in the country. The Art Auctions have brought a refreshing experience to art sales equating the Nigerian experience to experience in the Western world. In the 1960s, art centers used to be located in Lagos, Ibadan, Benin, and Enugu. From the 1980s, the art centers in Nigeria have expanded to include almost all capital cities of Nigeria. Bayelsa State is yet to join in the States of Nigeria where contemporary art has become a professional experience. The contemporary art space in Yenagoa (the Capital city of Bayelsa) is actually just gathering momentum. Whatever is available on the art scene is a subsistent development, carried over from Rivers State, from which Bayelsa State was carved out in 1996. 
Since 1996, Bayelsa has its capital at Yenagoa, and has existed under four democratically elected governments. The contemporary art scene in Bayelsa is nurtured mainly by the practicing artists, and art departments of the higher institutions in the State. Bayelsa is known to have one of the largest crude oil and natural gas deposits, thereby having prevalent petroleum production. However, most Bayelsans live in adject poverty due to decades of neglect by the government and petroleum companies. The State lacks basic amenities like adequate transport system, health-care facilities, and educational infrastructure. This poor condition of the socio-economic terrain has affected every sector including the arts and artists. Since the necessary structures needed to foster the growth of art is lacking, the contemporary artists have hardly risen to recognition in Nigeria. Migration to other places outside Yenagoa is a common feature among artists of the State. Many of the artists seek greener pastures that are often available in other places outside the State.

Accordingly, most of the present day artists in Yenagoa, whose work have enriched the contemporary art scene in the State within the past two decades (1996 to 2016), have not gained much recognition as their counterparts elsewhere in Nigeria, such as those in Lagos, Abuja, Benin, Enugu, amongst others. The reason for this unfortunate circumstance could be linked to lack of those basic elements or factors that aid the growth of art in the State. The development of an artistic ecology naturally depends on a number of factors, and these factors include fostering agencies like galleries, museums, art criticism, and the socio-psychology of the environment (Shyllon, 2013). Other factors include cultural foundations and institutions, auction houses, and robust art scholarship program by the government. Art writing in the dailies and magazines, conferences, art exhibitions; television programmes, and talk shows on art are essential to the development of art in any society. Some of these elements abound in Abuja, Lagos, and many other capital cities and metropolis of many states of Nigeria. Yenagoa on the contrary, is yet to develop on that direction as the aforementioned ambience or artistic ecology that art thrives on, are not available.

A view of the daily and weekly programmes of the State-owned, and private television channels show a lack of programmes or talk shows on Art. Another frustrating condition for the arts in Yenagoa is the fact that Art criticism and Art writing in the dailies and magazines are non-existent. Apart from the fact that there are no art galleries in Yenagoa, another problem encountered is the issue of patronage. There is a low clientele, due to lack of art collectors and dealers. These problems are linked to the questions: What artistic events and programmes are regularly organized Yenagoa? What are the factors confronting the growth of contemporary art practice in Yenagoa? What contemporary art productivity flows in Yenagoa from 1996 to 2016 ? What level of support has been received from the State Government, or other agencies to enhance positive growth of contemporary art in Yenagoa? This paper seeks to answer these questions by investigating and discussing those factors confronting contemporary art practice in Yenagoa.

\section{Indigenous Bayelsa Artists and the Old Rivers State}

Before the creation of Bayelsa State, artworks of artists from the current Bayelsa State, who were then referred to as indigenes of Rivers State, had enriched the art scene of the old Rivers State. The contributions of indigenous artists from Bayelsa, then domiciled and working in Rivers State is exemplified by such works as those of Late Prof. Jackson Ayerite Waribugo, whose artworks adorn Port Harcourt, the capital city of Rivers State. His artworks include such sculptures as the Mangrove Giant located at the Hotel Presidential, and the Oil King. Since the creation of Bayelsa State in 1996, mainstream Nigerian artists from the State are yet to relocate to the State. Many of them live within the Port Harcourt metropolis and other parts of the country and the world. That notwithstanding, the art and artists in Bayelsa State are gathering momentum. Bayelsa is yet to join in the artistic expansion which has been experienced in the nation since the 1980s. Perhaps, the formation of the State as one of the latest of States created by the Federal Government of Nigeria could be responsible for this.

\section{Contemporary Art in Yenagoa}

For over two decades now, since the creation of Bayelsa State till date, the art and artists in Yenagoa have had their fair share of challenges bordering on space, and lack of sponsorship for the artist. It is not surprising therefore, that Yenagoa is yet to join the other State Capitals of the nation where contemporary art has become a professional experience. Although what is available on the art scene is currently on a low ebb, the artists still organize exhibitions that are generally informing the emerging art consciousness in the society. However, Apart from the recent effort of the Society of Nigerian Artists (SNA) to bring the art market to Yenagoa through the Tidal Spectrum Art exhibition, only a few has actually been successfully held. Apparently, ten years after the creation of Bayelsa State, in 2006, one exhibition entitled Bayelsa at Ten marked the beginning of an actual planting of art in the State. It began to create the awareness of an emerging art conscious society.

In 2008, the Bayelsa State government co-sponsored the African Regional Summit and Exhibition on Visual Arts (ARESUVA), held in Abuja, the nation's capital city. The involvement of the State government enabled artists from the State to have an exhibition stand at the pavilion of the main event. Several indigenous artists from Bayelsa including Pius Waritimi, Pamela Cyril-Egware, Panebi Jones, Perin Oglafa, Diseye Tantua, 
and Favour Jackson participated in that exhibition (Amah, 2016; personal interview). Since then, there is hardly any governmental support for the visual arts in the State. Successive governments have not patronized or encouraged the trend. It is not encouraging to note that the Bayelsa State Government House is largely adorned with mass produced works of art from Dubai and other parts of the world. This is instructive on the neglect of the art produced by indigenous and domiciled artists of the State in the nation.

Before the establishment of the Bayelsa Chapter of the SNA in 2012, artists of the State origin had exhibited jointly with the artists in the old Rivers State. They had a joint Rivers/Bayelsa Chapter of the SNA from 1996 when Bayelsa State was created, up till 2012 when a separate Chapter for Bayelsa State was formally established, with Timipre Willis Amah as its first elected President. Afterwards, the State Chapter of the SNA had the maiden exhibition (Tidal Spectrum) in 2014, where twenty-eight artists featured. Since then, it is yet to organize another exhibition of such magnitude (Amah, 2016; personal interview). This could be linked to the present economic downturn besetting the nation. Perhaps, this would be viewed from the Maslow's pyramid of the hierarchy of needs, associated with self-actualization as the least of all the needs (Saul, 2007).

Despite being an oil rich state, the wealthy class, otherwise called 'money barons' in local terminology, who often patronize art, are not found in Bayelsa State, as it is a core civil servant State. Many of the people live rural and substandard life. The government, which should have been the major patron of the arts, has totally neglected the sector. Presently, the Bayelsa State Council for Arts and Culture promotes only performance art of drama and dance, to the detriment of the visual arts. Government intervention in these areas is evident from the many competitions that these genres of the arts have won for the State at national outings (Russia, 2016; personal interview).

Visual art is yet to receive attention like these other arts, and has not enjoyed such benefits. Most especially, art is hardly taught at the senior secondary level in most of the secondary schools in Bayelsa state. This should have been the right avenue to breed aspiring artists from an early stage. Ironically, the Niger Delta University (NDU) and other higher institutions of learning in the State have art departments to nurture students, who in most cases have not had previous background in art training at the primary and secondary school levels. These art departments in the State have been able to train a few artists. Some of them have graduated, and are making their input to the emerging contemporary art scene in Yenagoa. Due to the low level of patronage for the arts, most artists in the State look to paid employment with the government for survival, thereby shifting focus from their art.

\section{Wilberforce Island Connections}

The art department of the Niger Delta University (NDU), Wilberforce Island, has been the major hub for the proliferation of artists in Bayelsa State. The art teachers have been instrumental in contributing to the direction of the artistic trend in Yenagoa, the Bayelsa State capital. Worthy of note, are a few lecturers with the NDU, whose contributions have led to innovative artistic development within the department. Professor Mrs. Bridget Nwanze initiated the idea for an Annual Convocation Arts Exhibition for graduating students. It gave rise to 'Echoes of Talents', the first convocation exhibition in 2009, to showcase the potentials of graduating students from the art department (Echoes of Talents catalogue, 2009).

The exhibition was curated by Professor Mrs. Bridget Nwanze, with Professor A.A. Neto Emiemokumo as coordinator. Other facilitators of that exhibition include; Professor W.S. Ganagana, J.N. Tubonimi, Dr. S.G. Mangiri; Dr. S. Ebigbagha, Dr. A. Etuokwu, F. Ofori, Tobenna Okwuosa, and P.O. Waritimi. By attempting to organize annual convocation exhibitions, they have drawn attention to the ways in which students see and interpret their individual perceptions of their cultural environment (Echoes of Talents catalogue, 2009). Over the years, countless number of students have graduated with honours from the department, specialising in the various areas of the field. The Federal University in Otuoke (FUO), and the Isaac Jasper Boro College of Education, Sagbama (IJBCOE), are the other institutions of higher learning where artists are trained, although nothing of much significance has been recorded for them so far.

\section{The Exigency of Basic Art Education}

Majority of the secondary schools in Yenagoa do not teach creative art as a subject. In most cases, art teachers posted to the schools are directed by the school administrators to teach other subjects as they do not see the relevance of art as a subject area. Although the school curriculum make provision for art teaching and learning, art teachers are very few, and school administrators take advantage of the few number to obliterate art teaching. Ebi Odogu, a Technical Education teacher at the Central Epie High School in Yenagoa, revealed that the period affixed for fine art on the timetable is either free, or used for other subject areas since no fine art teacher has been posted to the school (personal interview, 10/05/2018). In some of the schools where there are art teachers, they are mostly restricted to teach only drawing and painting at the junior school level. Persaud (2015), states that education is the bedrock on which a nation stands. In that regard, there is felt need for intensive art education from cradle, if art is to thrive. Art education is indispensable if artists are to be proliferated in Yenagoa, the 
capital city of Bayelsa State.

Opuzi Eneli, a Chief Director of Education at the Bayelsa State Ministry of Education, regrets the misunderstood and neglected state of fine art in secondary schools in Yenagoa by school authorities. She confirms the absence of fine art teaching at the Senior WAEC level, and decries the attitude of school authorities by compulsorily reassigning fine art teachers posted to their schools to teach other subjects. It is sad to note the derogatory manner at which art is still viewed by some education administrators. The effort of Opuzi to reverse this unacceptable situation only succeeded in landing the teachers in teaching fine art to the lower classes of learning with a focus on drawing, relegating other relevant areas such as sculpture, art history, photography, etc, to the background.

For art to flourish in Yenagoa, the government has a role to play, especially in the area of robust scholarship programmes for studies in art. Ebikibina Ugo, a Director at the State Scholarship Board, regretted the paucity of scholarship awards for the Creative Arts. He says "when Sylva was in power, a lot of students were sent abroad. Some left for Sweden, Belarus, Russia, Malaysia; but amongst the lot, there was no single creative art" (personal interview, 18/03/2016). Sadly, the government emphasizes Engineering and the Sciences only. The State Council for Art and Craft which is saddled with the responsibility of art sponsorship is poorly funded, and can hardly initiate beneficial programmes for the artist. Russia Inei, a member of the State Chapter of the SNA, and current Head of the Sculpture unit, State Council for Art and Craft (SCAC), insisted that in terms of funding, "the SCAC has not contributed in any way to promote the visual arts in the State" (personal interview, 04/02/2016).

\section{Governmental Funding for Contemporary Nigerian Art}

The budget of the government for the support of contemporary Nigerian arts and artist has been noted to be on a decline. This is a sad situation for a nation in which art has become a professional experience. On the New Frames annual juried art exhibition catalogue (2015), organized by the Rivers State chapter of the Society of Nigerian Artists (SNA), is an articulation by Oliver Enwonwu, then National President of the SNA. It traced the fast dwindling budget for the visual arts (now classified as non-essential), to the fast dwindling Nigerian economy and an apparent apathy for the visual arts by both public and private sectors. It posits that neglect for the arts is exemplified by the sale of the National Theatre in Lagos, and the present condition of the National Gallery of Art, which now mainly exists only as administrative offices. In a reaction to such challenges, Sowole (2011, para. 4,5,\&6) declares that in Nigeria, there "is a zero-support of government for the arts". He further notes that:

In Britain, the Arts Council England, which distributes money to hundreds of art venues, groups, individual artists and galleries was established in 2003 from the 1940 establishment, Committee for Encouragement of Music and the Arts (CEMA). In Nigeria, what appeared like an equivalent started with a 1991 act known as National Endowment for the Arts. After two decades of silence, it took a build-up to the 2011 general elections for the government to remember the importance of arts funding, hence the recent announcement of " $\$ 200 \mathrm{~m}$ investment of Federal Government in the entertainment industry." However, the involvement of the Bank of Industry (BOI) as the managers of the fund, which, apparently, is a deviation from the grant structure expectation, seemed to have melted the earlier excitement the announcement of the fund generated within the arts sector.

Sowole feels that in a country such as Nigeria where so much money made from oil and other revenues end up in the management of a large government, and not in the areas of developing human resources, grants for artists, sadly, appears elusive. However, the Nigerian Minister of Information and Culture, Alhaji Lai Mohammed on July $31^{\text {st }}, 2017$, disclosed that the Federal Government has succeeded in securing a N300 million start-up loan from the Bank of Industry to support young talents in the arts sector (Vanguard, 2017). In spite of the Minister's disclosure, the government is yet to make available, information to Nigerians on how to access these funds. This has been a limitation for the arts and artists in the nation. However, the contributions of a few artists in Bayelsa have been instrumental for the amelioration of the artistic ecology in the State.

\section{Art, Media, and Space}

It has been established that the development of an artistic ecology naturally depends on a number of factors. These factors include fostering agencies like galleries, museums, art criticism, cultural foundations and institutions, auction houses, and robust art scholarship program by the government (Shyllon, 2013). Unfortunately, the abovementioned ambience or artistic ecology that art thrives on are not available in Yenagoa. However, it is expected that artists resident in Yenagoa should create initiatives that are essential to the development of art in order to attract art investors. One avenue through which art investors can be attracted to Yenagoa is by organizing conferences, and hosting regular exhibitions. Art writing in the dailies and magazines will help inform the gradually developing artistic socio-psychology of Yenagoa. Nevertheless, practicing artists in Yenagoa attribute the non-existence of regular exhibitions to the unavailability of space. Denison Zeekeyi 
Yibowei, Artist and Lecturer with the NDU, in an interview (11/02/2016), pointed out that one of the major problems faced by the artist in Yenagoa is space. According to him, "one of the challenges we are having is space. We don't have galleries, and show rooms, even the older and more experienced artists are scared of establishing one because it is cost intensive." Dennison reveals that connoisseurs, curators, and art dealers as well, have the mindset that the best place to source for art is Lagos, Abuja, or Port Harcourt. But then, some of the artists that go out there to exhibit are from Bayelsa. Dennison feels that it will be best if artists start having regular exhibitions in Yenagoa, in order to attract the art market. He is convinced that the fear of art investors is pointed toward a misguided belief that the artists in Yenagoa are not well grounded, which he regarded as not being true.

The conspicuous absence of cultural foundations like Alliance Francaise, and non-existence of partnership or support from multinational companies such as Total E\&P (with a reputation for providing space and funding for professional and budding artist) in Yenagoa is noted to be a major setback for contemporary art practice in the State. Notwithstanding, artists resident in Yenagoa are expected to be relentless in their effort to ameliorate the artistic ambience in Yenagoa. It must be noted that Lagos has been the hub of activities for modern and contemporary art in Nigeria, until the emergence of Abuja as the capital of Nigeria in December 12, 1991. Since then, these two cities have become leading centers for art and the places of desire by artists. This is because of the commercial and cosmopolitan nature of these two places. It has made them some "Mecca" of some sought for artists who want to grow and sell their art in the nation. Of course there are other cities like Kaduna, Ibadan, Enugu, Port Harcourt, Benin, Abeokuta, Minna, amongst others where contemporary art is of high value. Artists of Bayelsa State origin and indeed all parts of Nigeria would naturally drift to such towns. For example, Diseye Tantua, a contemporary artist and Chairman of the Society of Nigerian Artists (SNA) Port Harcourt branch, is an indigene of Bayelsa. He is based in Port Harcourt, where he makes portraits and paintings, and would not have been well known if he did not extend his presence to Lagos. He has his works in galleries and participates in exhibitions. Tobenna Okwuosa (personal interview, 25/02/2016) explained that although what happens in Lagos is more important and much more talked, much documented, and much valued than what happens elsewhere in Nigeria, it does not mean that other places should not thrive. Citing El Anatsui who lives in a remote village in Nsukka, but vastly recognized for his art, Tobenna throws the challenge on artists in those other places, calling on them to raise their art consciousness by creating spaces and events for their art.

\section{Conclusion}

Nigeria, known for its richness in arts and culture, due to its heterogeneous ethnic groups, has a number of art galleries. There are also museums. Numerous art exhibitions are often organized all over the nation. In Yenagoa, the planted seed of art is ill-watered by a lot of circumstances. There is therefore a slow growth of the Nigeria contemporary art practice in Yenagoa. Despite the limitations in Yenagoa, a few artists work tirelessly in their studios producing artworks. Occasionally, they partake in group and solo exhibitions, trying to create an art conscious society. That notwithstanding, much is needed to be done if a positive artistic expansion should be achieved. There is need for the private sector to intervene. Most of the auction houses and galleries in Lagos are put in place by the private sector. A level of synergy between the artists, the government, and art investors could salvage this ordeal besetting art and artists in Yenagoa. What is expected is regular exhibitions in art spaces within Yenagoa, if Bayelsa must join in the States where art is currently enjoying a professional experience. The growth of contemporary art in Yenagoa chiefly depends on a synergy from the government, the private sector, and the artists practicing within its geographical confinement.

\section{References}

Department of Fine, Industrial \& Theatre Arts (2009). Echoes of Talents Exhibition Catalogue. Faculty of Arts. Niger Delta University, Amassoma, Bayelsa State

McKean, C.A. (2015). Curator Okwui Enwezor Tackles Grim Realities at Venice Biennale, While Japan Sticks to Tired Festival Formula. The Japan Times LTD. Retrieved February 16 ${ }^{\text {th }}$ 2016, from: https://www.japantimes.co.jp/culture/2015/06/04/arts/curator-okwui-enwezor-tackles- grim-realitiesvenice-biennale-japan-sticks-tired-festival-formula/

Murrell, D. (2008). African Influences in Modern Art. (Essay section, para.1). Retrieved November 11, 2015, from https://www.metmuseum.org/toah/hd/aima/hd aima.htm

Persaud, K. (2015). Education is the Bedrock. Stabroek News. Retrieved May 14, 2018, from: https://www.google.com.ng/amp/s/www.stabroeknews.com/2015/opinion/letters/07/28/e ducation-is-thebedrock/amp/

Saul, M. (2007). Maslow's Hierarchy of Needs. Retrieved September 13, 2016. From: https://www.simplypsychology.org/maslow.html

Shyllon, Y. (2013). Problems of Art Development in Nigeria, para.1, and 3, Retrieved September 2, 2015, from: www.pmnewsnigeria.com/2013/12/04/problems-of-art-development-innigeria/ 
Society of Nigerian Artists; Rivers State Chapter (2015). New Frames Annual Juried Art Exhibition Catalogue. Hotel Presidential, Port Harcourt

Sowole, T. (2011). How Not To Fund Arts in Nigeria. Retrieved October 27, 2017. From: africanartswithtaj.blogspot.com.br/2011/09/funding-art-in-nigeria.html?m=1

Vanguard (2017). FG To Support Talented Art Youths with Start-up loan of N300m-Lai Mohammed. Retrieved July 31, 2017, from: www.vanguardngr.com/2017/fg-support- talented-art-youths-with-start-up-loann300m-lai-mohammed/ 